\title{
Las fotografías más antiguas del AGN, en papel salado, procedentes del registro de ladrones de la Cárcel Nacional de Belem
}

The Oldest Photographs of the AGN, on Salt Prints, Coming from the Criminal Registry of the Cárcel Nacional de Belem

\author{
Ana Lilia Quintero Barajas \\ Departamento de Acervos Gráficos y Certificaciones \\ Archivo General de la Nación \\ aquintero@agn.gob.mx
}

Recibido: 13 de julio de 2017 • Aprobado: 17 de octubre de 2017

Cómo citar este artículo: Ana Lilia Quintero Barajas, "Las fotografías más antiguas del AGN, en papel salado, procedentes del registro de ladrones de la Cárcel Nacional de Belem", en Legajos. Boletín del Archivo General de la Nación, núm. 15 (enero-abril 2018), pp. 103-127.

\section{Resumen}

Los documentos históricos sobre soporte fotográfico más antiguos con que cuenta el Archivo General de la Nación forman parte de dos expedientes del Fondo Archivo de Guerra, son copias al papel salado con fechas de manufactura aproximada de abril y junio de 1855. Fueron hechas presumiblemente por el coronel José Muñoz, Fotógrafo de la Cárcel Nacional de Belem y responden históricamente a la necesidad política de nuestro país de reglamentar y renovar el sistema jurídico y penitenciario utilizando la fotografía como un adelanto científico útil para el control y clasificación de los criminales. La toma de retratos para la identificación de reos permite reconstruir las gestiones administrativas de la Comandancia de la Ciudad de México para la administración de justicia.

Palabras clave: fotografía, papel salado, identificación, reos, cárcel

\section{Abstract}

The oldes Historical documents about photographic support in the Archivo General de la Nación take part on two files of Fondo Archivo de Guerra, these are salted paper copies with manufactures dates between april and june 1855. They were made supposedly by Colonel José Muñoz, Photographer of Cárcel Nacional de Belem and it responds historically to the political need of our country about the regulation and renewal of the legal and penitentiary system using photography as a useful scientific advance for the classification and control of criminals. Portrait taking for identification of prisoners allows the reconstruction of administrative managements of the Mexico City Commandancy for justice procurement.

Keywords: Photography, salted paper, identification, prisoner, jail 


\section{Introducción}

Los fondos y colecciones que resguarda el AGN son invaluables no solo por la información que podemos encontrar en ellos y que nos permite reconstruir el devenir histórico de nuestro país, sino también por la naturaleza misma en la que están constituidos.

Los acervos del AGN están integrados por fondos documentales, gráficos, bibliohemerográficos, audiovisuales y sonoros. La morfología, información, antigüedad y el estado de conservación, representan todo un reto en cuanto a la política de gestión documental con que son abordados dichos fondos y las especificidades con que son tratados.

Uno de ellos es el patrimonio cultural sobre soporte fotográfico, el cual está integrado por una multitud de procedimientos y de estructuras morfológicas diferentes, fascinantes y complejas.

La copia al papel salado es la técnica fotográfica más antigua que se ha encontrado hasta la fecha, en el AGN, debido a la naturaleza de las incorporaciones y donaciones que recibe, en su mayor parte de la Administración Pública Federal. Procesos fotográficos anteriores al papel salado, como daguerrotipos, ferrotipos y negativos de colodión húmedo, no se han localizado como parte de alguno de los acervos que se resguardan, pues este tipo de procesos pertenecen, en su mayoría, a colecciones particulares y son muy apreciadas por su gran valor histórico, su belleza y perfección.

En este trabajo se analizarán las fotografías en papel salado localizadas en el AGN. Éstas se realizan de acuerdo con su morfología y elaboración, así como al contexto histórico en que están situadas, sin olvidar el contenido de los expedientes el cual es básico para entender ambas cuestiones y que hasta el momento ha pasado desapercibido por las investigaciones sobre historia de la fotografía.

Los expedientes donde se encuentran las imágenes analizadas corresponden a los volúmenes 47 y 777 de la sección Archivo de Guerra, que contiene la documentación generada por la Comandancia 
General de México y el Tribunal Superior Militar desde 1801 hasta $1876 .{ }^{1}$

La sección Archivo de Guerra, actualmente pertenece al Fondo Guerra y Marina antes Ministerio de Estado y del Despacho de Guerra y Marina, cuya documentación ingresó al Archivo General y Público de la Nación entre 1889 y $1890 .^{2}$

Del volumen 47 se analizará la "Causa instruida contra Candelario Loa y cómplices". Acusados de robo y asalto en despoblado y en cuadrilla, cometido en el rancho de los Ailes, propiedad de Martín Aguilar, la cual inicia en agosto de 1854 y termina en junio de 1855.

Del volumen 777 se estudiará la "Causa instruida contra Laureano Rosas y cómplices". Acusados de robo con asalto y horadación en la casa número 2 del segundo callejón del Coyote, la cual inicia en agosto de 1853 y termina en abril de 1855.

Se considerarán estos dos casos específicos por la similitud de las diligencias y gestiones jurídicas realizadas en la Comandancia General de la Ciudad de México, por la proximidad de las fechas de conclusión de los procesos judiciales y la toma de retratos, pues las causas inician en años diferentes pero la conclusión de ambas es en 1855 y según la 9a. Cláusula del Reglamento: "para asegurar la identidad de los reos cuyas causas se sigan en la Ciudad de México". Especificaba que "solo se podrán publicar los retratos de reos cuyas causas estuviesen ejecutoriadas, y previo el permiso del inspector general

\footnotetext{
${ }^{1}$ La sección Archivo de Guerra cuenta con 1472 volúmenes empastados que van desde los años 1801 hasta 1876 e incluyen: causas criminales, lista de sumarias y procesos, órdenes de arresto, partes diarios, estados de fuerza, información sobre reos y presos en prisiones militares, gobierno de Antonio López de Santa Anna de 1853 a 1855, crímenes dentro del derecho militar y causas por robo y delitos comunes, sin conexión al servicio militar, que fueron juzgados por tribunales militares para dar un control más eficaz de dichos delitos los cuales se convirtieron en un problema constante a mediados del siglo XIX, entre otros.

${ }^{2}$ El AGN es el organismo encargado de recibir la documentación histórica generada por las diferentes dependencias de la Administración Pública y las fotografias que se incluyen en estos expedientes forman parte de los procedimientos que el Ministerio de Estado y del Despacho de Guerra y Marina llevaban a cabo.
} 
de prisiones, quien examinará los antecedentes para saber si es de utilidad su publicación". ${ }^{3}$ Es decir, los retratos se realizaban una vez que se concluían los procesos y eran aprobados por el inspector general de prisiones, por lo que ambos se efectuaron en 1855 con una diferencia de tres meses.

El análisis de las imágenes pretende demostrar:

1. La técnica de manufactura con que fueron realizadas, de acuerdo con sus características físicas y la autenticidad de ésta.

2. La temporalidad en que fueron hechas.

3. La presunción de que fueron elaboradas por el coronel José Muñoz, fotógrafo de la Cárcel Nacional (de Belem).

El análisis histórico considerará:

1. La necesidad de control administrativo y social que nuestro país padecía a mediados del siglo xix, después de la Guerra de Independencia.

2. Los deseos apegados a la filosofía liberalista de dar al país una estabilidad política, y de "igualar" a la población.

3. El control que las autoridades ejercieron recurriendo a los últimos adelantos tecnológicos para la mejora del sistema carcelario, en este caso, la fotografía.

4. La utilización de la fotografía para mejora del sistema carcelario y de salud pública utilizado por esa administración como un adelanto e innovación tecnológica característica de la época.

5. El papel salado como nuevo procedimiento fotográfico que permitió realizar copias en serie del retrato de los criminales para así tener un mayor control sobre éstos.

6. Las características específicas de cada caso, las cuales responden al contexto histórico de la época, el proceso judicial y las diligencias para su administración.

${ }^{3}$ Debroise, Fuga mexicana, pp. 70-71. 


\section{Técnica de manufactura e identificación de proceso fotográfico}

El papel salado fue una técnica de impresión fotográfica por contacto sobre papel, ${ }^{4}$ patentada por Fox Talbot en 1840; este método surgió casi a la par que el daguerrotipo, ${ }^{5}$ sin embargo, la utilización del negativo permitía realizar numerosas copias en positivo-papel y el abaratamiento de costos en la manufactura.

Una de las caras del papel era cubierta con una solución de sales de cloruro de sodio la cual se dejaba secar para posteriormente cubrir con otra solución de sales de nitrato de plata, después se exponía directamente a los rayos ultravioleta del sol con un negativo superpuesto, se lavaba y fijaba finalmente dando como resultado una imagen en positivo de alta calidad. Los papeles salados más antiguos (1840) se realizaron por medio de un negativo hecho de papel encerado llamado calotipo, posteriormente se hicieron a partir de un negativo con soporte de vidrio al colodión húmedo, el cual era tomado directamente por una cámara. ${ }^{6}$

La característica del papel salado es que cuenta con un soporte de papel muy delgado, comúnmente de algodón, y las sales de plata formadoras de la imagen se encuentran embebidas en las fibras de éste; presenta una coloración café o café-rojizo al no tener aglutinante que proteja las partículas de plata; éstas se oxidan y pueden destruirse dando como resultado desvanecimiento o pérdida de densidad y amarillamiento de la imagen. ${ }^{7}$

Se presume que las imágenes que son utilizadas para esta investigación fueron realizadas en papel salado pues cuentan con las siguientes características:

${ }^{4}$ Superposición de un negativo sobre el papel fotosensible.

${ }^{5} \mathrm{El}$ daguerrotipo fue el primer proceso fotográfico que existió (1839), se trata de una placa de plata o cobre cubierto con un baño de plata sensibilizada por vapores de yodo y expuesta directamente en una cámara dando como imagen final un positivo directo, único e irrepetible.

${ }^{6}$ Valverde Valdés, Los procesos fotográficos históricos, p. 48.

${ }^{7}$ Valverde Valdés, Los procesos fotográficos históricos, p. 48. 
1. Las imágenes presentan tonos café-rojizo o púrpuras, propios de las impresiones al papel salado, que fue la primera técnica de impresión fotográfica realizada con un negativo en contacto con un papel foto sensibilizado y por ennegrecimiento directo de los rayos del sol o Dop (por sus siglas en inglés). ${ }^{8}$

2. El papel no cuenta con un aglutinante ni capa de sulfato de bario pues las fibras de papel son claramente visibles al analizar la imagen por medio de un microscopio sencillo (60X-100X).

3. La superficie del papel tiene un acabado mate (no brillante), como podría esperarse en caso de ser una albúmina.

4. Se observa pérdida de densidad o desvanecimiento, sobre todo en las altas luces de la imagen, lo que impide diferenciar la ropa clara de los personajes con el fondo, este desvanecimiento es otra de las características de esta técnica.

5. Las fechas en que fueron hechas las imágenes (1855) corresponden con la temporalidad y uso del papel salado (1840-1865). ${ }^{9}$

6. Las características del papel de fibras de algodón y de lino de los expedientes a los que pertenecen, las filigranas y el uso de tintas ferrogálicas utilizadas en estos documentos son una muestra más de dicha temporalidad.

\section{La fotografía: tecnología de criminólogos y penalistas}

El siglo xix estuvo marcado por la necesidad universal de clasificar científicamente las cosas y las personas para conocerlas. A principios de dicho siglo, por medio del grabado y la litografía, se buscó ilustrar publicaciones periódicas, catálogos de botánica y zoología, álbumes de tipos populares, escenas de batallas, inventarios sistemáticos de sitios arqueológicos, y por supuesto identificación de presos y tipos criminales. Los científicos decimonónicos constantemente viajaban con un dibujante para tomar apuntes de sus investigaciones, mismos que se

\footnotetext{
${ }^{9}$ Developing Out Paper.

${ }^{10}$ Valdez Marín, Conservación de fotografia histórica y contemporánea, pp. 41-42.
} 
reproducían en talleres litográficos, para darlas a conocer a un público ávido de conocimientos. ${ }^{10}$

A mediados de ese siglo una nueva técnica empezó a ganarle terreno al dibujo litográfico, la fotografía representó un descubrimiento per se para el mundo científico ${ }^{11}$ y el poder utilizarla como un medio de control social sobre los individuos que transgredían el orden que se buscaba, fue una de sus características en este periodo.

Las autoridades en el México decimonónico fueron muy pronto sensibles a la utilización del nuevo procedimiento de la fotografía como instrumento de control e identificación de criminales. Nuestro país fue pionero en la normalización de la toma fotográfica para asegurar la identidad de los reos, por lo menos una década antes que en muchos otros países, donde se generalizó hasta $1860 .{ }^{12}$

En 1855 se reglamentó en la Ciudad de México el uso de la fotografía para el control e identificación de los reos - por decreto presidencial de Antonio López de Santa Anna-, tal vez a iniciativa del inspector de Cárceles del Ayuntamiento, Miguel Hidalgo y Terán, pues se consideró que de esta manera sería mucho más fácil para la policía el reconocimiento y el control de los reos. Incluso existió un reglamento para asegurar la identidad de los reos cuyas causas se sigan en la Ciudad de México, del 14 de marzo de $1855 .{ }^{13}$

Posteriormente, el regidor del Ayuntamiento de la Ciudad de México, J. M. Cervantes Ozta, en una carta dirigida al gobernador del Distrito, Antonio D. Bonilla, con fecha del 22 de abril de 1856, argumentó "muy suficientemente" la conveniencia de establecer "en la Cárcel Nacional, de una manera permanente, la fotografía para obtener por medio de ella el retrato de los reos que la comisión designe", para la "adecuada y pronta administración de justicia". ${ }^{14}$

\footnotetext{
${ }^{10}$ Aguilar Ochoa, Las glorias nacionales. Constantino Escalante, Hesiquio Iriarte, p. 23.

${ }^{11}$ La fotografia representó un enorme descubrimiento científico en el que se fusionaron ciencias como la química, la física y la óptica.

${ }^{12}$ Lerner, El impacto de la modernidad..., p. 25.

${ }^{13}$ Debroise, Fuga mexicana, pp. 70-71.

${ }^{14}$ AHDF, “Ayuntamiento, Empleados cárceles. Fotógrafos", vol. 897, exp. 1.
} 
Hace tiempo se proyectó, aunque de un modo imperfecto, introducir en la Cárcel Nacional una mejora reducida a sacar por el daguerrotipo los retratos de los reos más famosos. Desde luego se echa de ver que el objeto de esta providencia era que por medio del retrato hubiera una constancia de las señas individuales de los reos, que daría mejores resultados que la simple filiación y pudiera servir, como se ha verificado ya, para que en caso de que algún criminal se fugase, fuera más fácilmente reprendido, porque producidos varios ejemplares de su retrato y repartidos a los agentes de policía de la capital o de las autoridades de fuera de ella, más fácilmente pueda producirse la persecución del reo. Además, con esta medida puede obtenerse un buen dato para la estadística criminal, porque la reseña histórica imperfecta hasta ahora, que el fotógrafo ha comenzado a formar y contiene el retrato de cada reo con más noticia de sus generales debe llevarse al más alto grado de perfección... ${ }^{15}$

Se buscaron, sin embargo, técnicas fotográficas mucho más baratas y tecnológicamente más accesibles que el uso del daguerrotipo, ${ }^{16}$ el papel salado permitió tener un negativo de las imágenes y poder reproducirlas hasta el infinito ya que se precisaban por lo menos cuatro copias de cada reo.

En México, a mediados del siglo xix, la fotografía no tenía aún la perspectiva "cientificista" con fines frenológicos ${ }^{17} \mathrm{o}$ antropométricos para la identificación del criminal que tuvo dentro del "positivismo" a finales de siglo, sino solo de control criminal como se sigue utilizando en la actualidad.

${ }^{15}$ AHDF, “Ayuntamiento, Empleados cárceles. Fotógrafos”, vol. 897, exp. 1.

${ }^{16}$ El daguerrotipo es una de las llamadas "imágenes de cámara", es decir, un positivo directo de la cámara sin un negativo previo; muy costoso por su técnica de manufactura. ${ }^{17}$ La frenología es un término creado por el médico vienes Franz Joseph Gall (17581828), el cual aseguraba que se podían conocer las tendencias morales de una persona y reconocer a un criminal por la forma y características de su cráneo. 
Las técnicas de identificación antropométrica de Alphonse Bertillón fueron aplicadas hasta finales del siglo xix, en 1887, en la Ciudad de México se puso en práctica el sistema Bertillon, método antropométrico que combinaba las mediciones corporales y la fotografía como un instrumento de control social. Ubicando el primer gabinete antropométrico en la Cárcel de Belem en 1895 el cual estuvo a cargo del doctor Ignacio Fernández Ortigosa. ${ }^{18}$

El médico italiano Cesare Lambroso, conocido como el padre de la criminología científica, formuló una teoría en la cual concebía el crimen como una tendencia genética observable en los rasgos físicos de los delincuentes y estableció una clasificación de estos. La teoría Lambrosiana gozó de gran popularidad en nuestro país desde finales del siglo xix hasta entrado el xx. ${ }^{19}$

\section{Fotógrafo de la Cárcel Nacional de Belem}

Para la década de los cincuenta del siglo xix en la Ciudad de México, el control de ciertos sectores de la población fue un tema primordial por la situación que enfrentaba el país. Éste se ejerció recurriendo a los últimos adelantos tecnológicos para la mejora del sistema carcelario, en cuyo caso la fotografía y la aparición de los llamados "funcionarios ilustrados"; el fotógrafo, lejos de llevar a cabo una labor artística en la toma de imágenes, se convirtió en el funcionario público a sueldo encargado de hacer posible el registro de criminales con la finalidad de sanear la ciudad de individuos indeseables.

Uno de los primeros fotógrafos de la Cárcel Nacional fue el coronel José Muñoz, quien permaneció en este puesto desde marzo de 1855 hasta 1860. Al momento de su nombramiento y por orden del presidente Antonio López de Santa Anna, se le entregaron 306 pesos para la compra de una "máquina y útiles necesarios para los retratos

${ }^{18}$ Debroise, Fuga mexicana, p. 31.

${ }^{19}$ Wordpress, 2013, Cesare Lombroso. Padre de la Criminología Científica, http:/sanchezlm. wordpress.com/2013/02/27/cesare-lombroso-el-padre-de-la-criminología-científica/ 
fotográficos de los reos de la Cárcel, Nacional" y se le otorgó una gratificación de 16 pesos mensuales, el 22 de marzo de $1855 .{ }^{20}$

Este fotógrafo es el autor atribuido de los retratos de los dos procesos judiciales que se analizan por robo en gavilla a casas particulares y son sentenciados a purgar su condena en San Juan de Ulúa.

El AGN cuenta con varios procesos judiciales que incluyen retratos de presos, realizados en papel salado y que van desde 1855 hasta 1858, época en la que trabajó José Muñoz en la Cárcel Nacional, por lo que se le atribuyen y se hace resaltar su destacable labor como fotógrafo en los primeros registros fotográficos del AGN.

\section{El racionalismo de la criminología en México}

Al finalizar la Guerra de Independencia, en 1821, la sociedad mexicana entró a su nueva realidad aquejada por las consecuencias que había dejado el reciente suceso histórico. Los deseos apegados a la filosofía liberalista de dar al país una estabilidad política, y de "igualar" a la población no lograron materializarse y entraron en confrontación con la realidad social del país: la inestabilidad política, la pobreza, el atraso cultural, la violencia, la desorganización social, la desarticulación administrativa y el infranqueable contraste social caracterizado por enormes diferencias raciales y de clase, fueron aspectos que los grupos menesterosos poco entendían pero que sin embargo resentían en el día a día.

La creencia de que las clases inferiores tendían hacia el vicio, la falta de inteligencia y las malas inclinaciones, como el robo y el bandidaje, fue unánimemente aceptada, en contradicción con el liberalismo, el cual se fundamentaba en la racionalidad de los seres humanos y la inviolabilidad de sus derechos. Se juzgaron como delictivas aquellas actividades con las que los grupos más pobres y marginados buscaron el sustento, el vestido y la distracción, no se consideró que las costumbres y valores de la población indígena, desde la conquista, hayan sido

${ }^{20}$ AHDF, "Ayuntamiento, Empleados cárceles. Fotógrafos", vol. 897, exp. 1. 
debilitadas o arrancadas de tajo y obligadas a aceptar una cultura impuesta creándoles un vacío social que buscaron llenar con actividades poco "toleradas" por las clases altas. ${ }^{21}$

La población tuvo que enfrentarse a un aumento, sin precedentes, de la criminalidad; debido a la escasez de alimentos como resultado de la crisis agrícola, el desempleo y la pobreza extrema, un gran segmento de la población vivió amenazado constantemente por el hambre; la única alternativa para no morir de inanición fue el bandidaje. Numerosas gavillas de ladrones (desertores del ejército o criminales) formaron bandas que asolaron caminos y robaron casas y haciendas, despojando a sus habitantes de lo poco o mucho que poseían. ${ }^{22}$

Los ladrones irrumpían en los tejados, forzaban u horadaban las puertas para el saqueo nocturno, los artículos eran vendidos en baratillos o tiendas de empeño donde podían cambiarlos por algún dinero para comer o beber.

El bandidaje incrementó a tal grado la tensión social que puso en peligro la autoridad gubernamental y el funcionamiento económico, los caminos eran el lugar privilegiado por las bandas para asaltar a los pequeños o grandes comerciantes que proveían de alimentos e insumos a ciudades y poblaciones.

Preocupados por las consecuencias que traería este aumento del crimen en la sociedad, los políticos y juristas mexicanos adoptaron sin más las nuevas ideas racionalistas de criminólogos y penalistas extranjeros. La reforma carcelaria fue un elemento indispensable para la llamada criminología científica que formulaba por medio de leyes racionales e instituciones organizadas volverían el crimen un acto indeseable. ${ }^{23}$

Este apego al racionalismo ilustrado adoptado por nuestro país y adaptado al discurso tradicional mexicano, lejos de ser coherente dejó entrever un sinnúmero de prejuicios clasistas arraigados en la elite, pues por una parte se buscó el igualitarismo de la sociedad y por la otra, las clases inferiores fueron vistas con desconfianza y temor,

\footnotetext{
${ }^{21}$ MacLachlan, La justicia criminal del siglo XVIII en México, p. 82.

${ }^{22}$ Vázquez, Historia general de México, p. 565.

${ }^{23}$ Buffington, Criminales y ciudadanos en el México moderno, p. 22.
} 
volviéndose mucho más severos los castigos, se siguió utilizando la pena de muerte. ${ }^{24}$

Durante la Época Colonial los indígenas acusados por robo no recibían sentencias relacionadas con el servicio militar; a partir de 1810, los grupos étnicos ya no tuvieron importancia para ser destinados a las milicias. ${ }^{25}$ Para 1853, los delitos de robo fueron sujetos a la jurisdicción militar y las penas fueron la muerte o el trabajo forzado en el presidio de San Juan de Ulúa. ${ }^{26}$

Para esta época los sentenciados por robo en la Ciudad de México comúnmente pasaban el proceso judicial en la Cárcel Nacional de Belem, mientras se determinaba si serían ejecutados, de acuerdo con las agravantes o atenuantes, o salían en cuerda a San Juan de Ulúa. Debido a la falta de recursos en la Administración Pública, los reos y los guardias que salían en cuerda, debían ir andando hasta su destino, sufriendo una agotadora caminata y las inclemencias del clima. Las fugas eran comunes, por lo que se buscó una forma de tener control o un registro de los presos, y la fotografía sirvió como medio para identificarlos y mejorar el sistema carcelario y de salud pública.

A continuación presentamos los procesos criminales que se siguieron a estos reos.

\section{Proceso criminal contra: Laureano Rosas, Rómulo León, Lorenzo Nájera, Sebastián Zereso, Manuel Rosas y Justa Varela. Plaza de México 1853-1855 ${ }^{27}$}

La madrugada del 14 al 15 de agosto de 1853 los ladrones Laureano Rosas, Rómulo León, Lorenzo Nájera, Sebastián Zereso y Manuel

${ }^{24}$ La pena de muerte fue un aspecto problemático para los juristas mexicanos decimonónicos, pues se consideraba un procedimiento bárbaro, pero también se pensaba que la sociedad no estaba preparada para prescindir de ella.

${ }^{25}$ Lozano Armendares, La criminalidad en la Ciudad de México 1800-1821, p. 179.

${ }^{26}$ Las penas correspondieron a las circunstancias especiales del momento.

${ }^{27}$ AGN, Archivo de Guerra, "Proceso criminal contra: Laureano Rosas, Rómulo León, Lorenzo Nájera, Sebastián Zereso, Manuel Rosas y Justa Varela. Plaza de México 1853-1855", vol. 777.

$114 \vdots \quad$ Número 15 (enero-abril 2018) • ISSN: 0185-1926 • ISSN-e: 2448-8798 
Rosas, cometieron el robo con asalto y horadación en cuadrilla en la casa número 2 del segundo callejón del Coyote, propiedad de doña Lugarda Aduna.

Esa noche a las dos de la mañana, un grupo de 10 malhechores horadaron la pared exterior de la casa con una bayoneta, abriendo un agujero por donde se introdujeron, forzaron la puerta interior de las habitaciones rompiéndola con espadas y bayonetas, se introdujeron a la pieza donde dormía Lugarda Aduna, Jorge Capetillo y su hija de 12 años Justa Capetillo, golpeando y amarrando a los dos padres. Dejaron a dos de los salteadores vigilando la entrada exterior que mira a la plazuela de Mixcalco para cuidar al guardafaroles y a los transeúntes que pudieran pasar.

Registraron la habitación solicitando las llaves de un baúl que poseían los dueños de la casa; ante la negativa de entregarlas lo rompieron y también otros muebles, descolgaron los trastes de vidrio y loza y sacaron lo que contenían los baúles llevándoselo.

Al otro día, los dueños de la casa creyeron reconocer a dos de los ladrones e hicieron que apresaran a Mariano Fragoso y Matías Padilla, posteriormente manifestaron estar equivocados y pidieron su liberación. Más tarde recordaron que el paisano Laureano Rosas los visitó sin tener motivo días antes del robo y solicitaron al cuartel mayor que lo apresaran, encontrándolo en la casa de su amante Justa Varela. Al pasar por el puente de Santiaguito llevándolo detenido, Rosas les propuso que lo dejaran libre y devolvería lo robado y les mostraría a los autores del robo a cambio de vivir en la casa de los Capetillo unos días junto con Justa Varela, llamaron a doña Mariquita Nieves Morejón para que hiciera una lista con los nombres de los salteadores que le dictaba Laureano Rosas. El documento pasó al general Manuel María Lombardini, comandante general, quien dictó órdenes para que el capitán Agustín Ordaz y una comisión de agentes de policía acompañara al matrimonio y aprendieran a los criminales; lo cual se verificó la noche del 19 de agosto.

En la plazuela de Pacheco apresaron a Lorenzo Nájera al salir de una tienda; en el Callejón del Marquesote aprendieron a Rómulo León, junto con otros dos acusados, éstos reconocieron a Rosas que 
iba disfrazado con un sombrero muy grande de petate y un zarape colorado y le recriminaron no haber denunciado a su hermano Manuel Rosas quien también participó del robo. Los detenidos confesaron haber concurrido al robo y fueron llevados a la Cárcel Nacional de la ex-Acordada. ${ }^{28}$

Días después, al ir caminando Lugarda Aduna con Justa Varela le señaló a Sebastián Zereso como cómplice del crimen, avisó a la comandancia y se aprendió a éste. Justa confesó que el día del robo, Laureano Rosas no llegó a dormir, diciéndole que iba a un fandango, al regresar comieron con tres reales que traía y pagaron una deuda, Rosas entregó a Justa unas prendas para que las empeñaran en las tiendas por el rumbo de Necatitlán conocidas como: de don Castro y del Torito donde se encontraron los objetos robados con los boletos de empeño de las cantidades pagadas y el nombre de los empeñantes que coincidieron con los de los reos, motivo más para su incriminación. ${ }^{29}$

Al ser aprendidos, sólo Rómulo León confesó haber asistido al robo, todos los demás lo negaron a pesar de las múltiples pruebas que se encontraron en su contra: la lista que hizo Laureano Rosas con los nombres de los ladrones, el reconocer al momento de ser aprendidos haber participado en el robo y platicar sobre la repartición del botín frente a la comisión de policía, los boletos de empeño con sus

${ }^{28}$ La Acordada fue una organización de voluntarios, autorizada por un real acuerdo de 1719, para la captura y enjuiciamiento de bandidos que asolaban el país a principios del siglo XVIII, por extensión se llamó así la cárcel que servía para el Tribunal de dicho nombre. Sus actividades comenzaron en la ciudad de Querétaro, en 1703, y posteriormente en la Ciudad de México, fue suprimida en 1812. Su nombre continuaría pese al título de Cárcel Nacional de Belem, Enciclopedia de México, t. 1, A-Arriaga, Dir. José Rogelio Álvarez, México, 1999.

${ }^{29}$ Por las listas de objetos que se incluyen en los expedientes por robo, sabemos que la ropa o piezas de tela eran de los objetos más requeridos, entre la loza, los muebles y las alhajas, pues la mayoría de la gente solo contaba con la ropa que traía puesta y era por lo tanto necesaria. Además, resultaba fácil empeñar o vender la ropa $\mathrm{u}$ objetos en los baratillos a cambio de una moneda con la cual comer o emborracharse. Los "leperos" o pelados cubrían sus desnudeces con harapos, muchas veces recogidos de la basura y comían precariamente. 
Ana Lilia Quintero Barajas Las fotografias más antiguas del $A G N$..

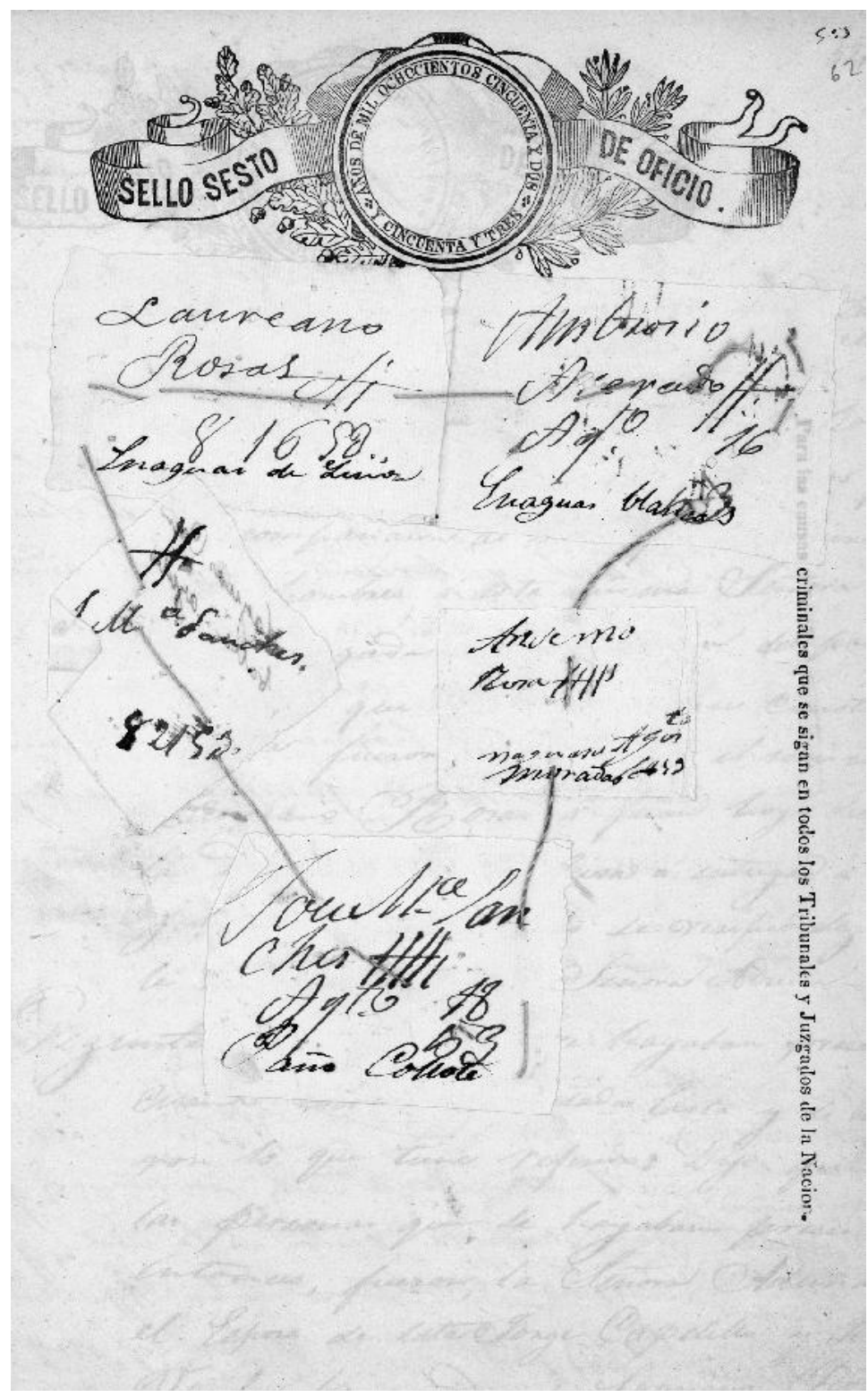


nombres y las contradicciones en las que cayeron en sus declaraciones al practicarse la sumaria que duraría tres años. ${ }^{30}$

El 3 de abril de 1854 se reunió en uno de los salones de la exAcordada el Consejo Ordinario de Guerra presidido por D. Manuel Ferris, teniente coronel del segundo batallón ligero permanente, donde estudiaron las causas y se interrogaron a los presos. Se concluyó lo siguiente:

\section{Que Laureano Rosas, Rómulo León, Lorenzo Nájera y Manuel Rosas sufran la pena de muerte en la forma ordinaria y que permanezcan sus cadáveres por tres horas a la expec- tación pública con arreglo de la Ley 18, título 14, partida 7a., ley 6a., título 5o., libro 4 del fuero real y a la 8a. titulo 31 partida 7a. Y a Manuel Rosas sufra la pena extraordinaria de 10 años de presidio conforme a la Doctrina de Villanueva, previa degradación de su empleo, hasta ese momento aún no se localiza a Manuel Rosas y a Domingo Balcazar. ${ }^{31}$}

La sentencia de muerte fue mandada ejecutar por el comandante general, se verificaría a las siete de la mañana el lunes 15 de mayo de 1854, en la Calzada del Paseo Nuevo, pasando la estatua de Carlos iv, se ordenó poner a los presos en capilla desde el 13 de mayo, mientras se disponía del verdugo y ayudante, pues el que estaba de servicio salió de la capital sin encontrársele, y ninguno de los reos que existían en la Cárcel Nacional quiso realizar la ejecución.

Sin embargo el 24 de mayo su alteza serenísima el general presidente Antonio López de Santa Anna dio a conocer el siguiente decreto:

Antonio López de Santa Anna, Benemérito de la patria, General de División, Gran Maestre de la Nacional y

${ }^{30}$ Constantemente se cambiaban a los oficiales subalternos de la guarnición que les eran asignados como defensores, durante el proceso aproximadamente cinco veces, lo cual retrasaba por años la conclusión de los procesos judiciales.

${ }^{31}$ AGN, Archivo de Guerra, "Proceso criminal contra: Laureano Rosas, Rómulo León, Lorenzo Nájera, Sebastián Zereso, Manuel Rosas y Justa Varela. Plaza de México 1853-1855”, vol. 777. 
distinguida orden de Guadalupe, Caballero Gran Cruz de la Real y distinguida orden de Carlos III y Presidente de la República Mexicana sabed: Que en uso de la facultades que la Nación se ha servido conferirme, he tenido a bien decretar lo siguiente: se indulta de la pena capital a que fueron condenados los reos Laureano Rosas, Rómulo León y Lorenzo Nájera y se les conmuta en la mayor de 10 años de presidio, por tanto mando se imprima, publique y se le dé el debido cumplimiento. Dado en Palacio del Gobierno General en México a 24 de mayo de 1854. Antonio López de Santa Anna. ${ }^{32}$

El 20 de este mismo mes el presidente Santa Anna mandó que Lorenzo Nájera cumpliera su condena en la Marina Nacional por 10 años. Posteriormente, son aprendidos Manuel Rosas hermano de Laureano Rosas y soldado del segundo batallón activo de la ciudad, Domingo Balcazar, soldado desertor del tercer batallón ligero permanente, que ocupaba el puesto de centinela en la Cárcel Nacional de Belem, y Justa Varela amante de Laureano Rosas. ${ }^{33}$

El reo Rómulo León entró al Hospital Municipal de San Pablo el 15 de junio de 1854, enfermó de la epidemia de cólera que azotó la Ciudad de México en la década de 1850 y murió en la cama 13 en la sala de recargados el 16 de junio de $1854 .^{34}$

${ }^{32}$ AGN, Archivo de Guerra, "Proceso criminal contra: Laureano Rosas, Rómulo León, Lorenzo Nájera, Sebastián Zereso, Manuel Rosas y Justa Varela. Plaza de México 1853-1855", Vol. 777.

${ }^{33}$ La pena de muerte comúnmente se sustituía por el presidio o trabajos forzados en fortificaciones de Perote o en San Juan de Ulúa por 10 años.

${ }^{34}$ Según Francisco Peña: "Las galeras de Belem, los dormitorios generales son de techo alto, cuentan con una letrina abierta en un rincón que despide un aroma pestífero y están provistos de petates para aproximadamente seiscientos presos. Estos pasan el tiempo acostados, fumando mariguana y tabaco". La falta de salubridad y de conocimientos médicos hacía que el tifo, la viruela y el cólera cobraran muchas víctimas. Francisco Javier Peña, Criminales y ciudadanos en el México moderno... p. 144. 
Ana Lilia Quintero Barajas

Las fotografias más antiguas del AGN...

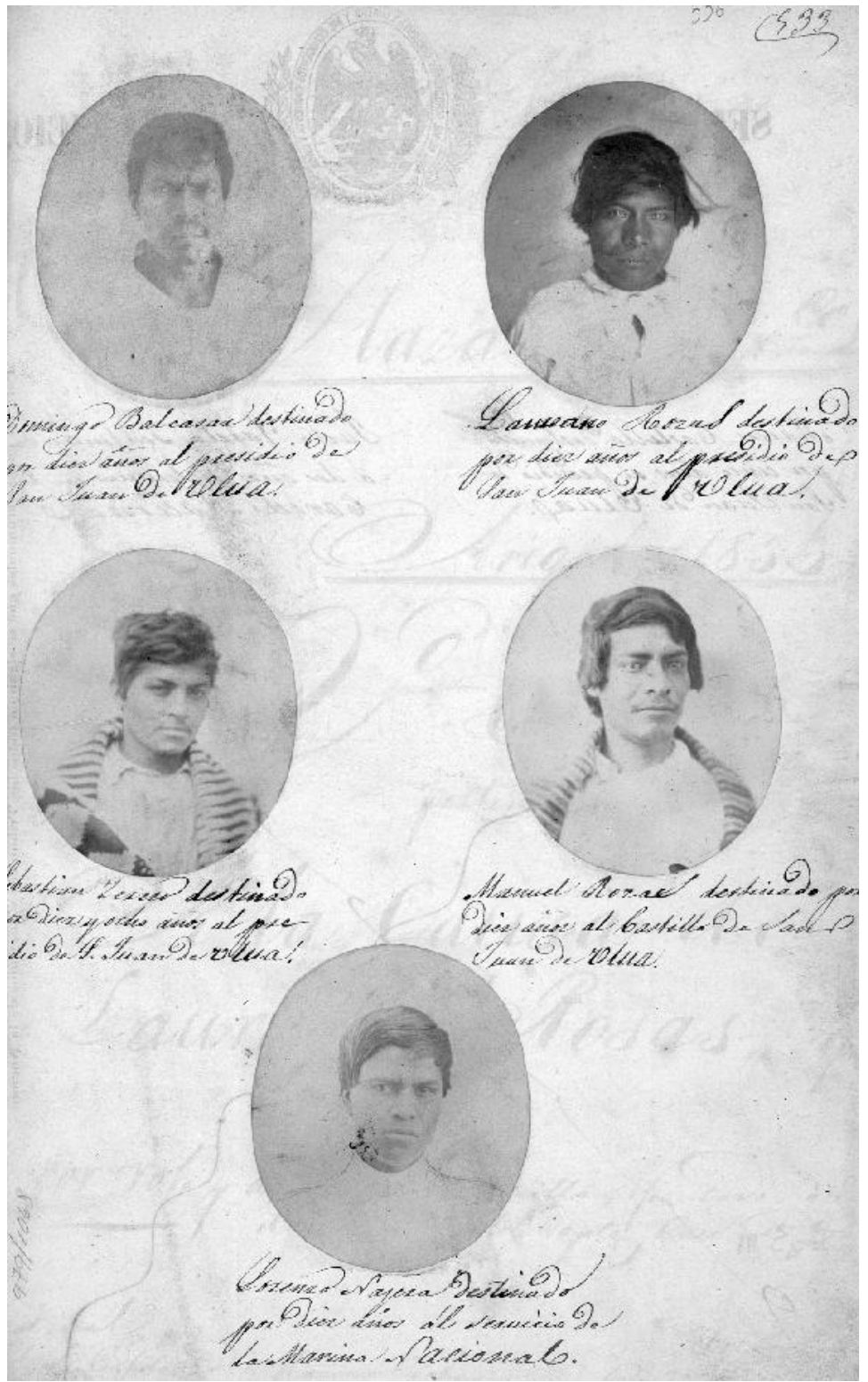


Ana Lilia Quintero Barajas Las fotografias más antiguas del $A G N$..

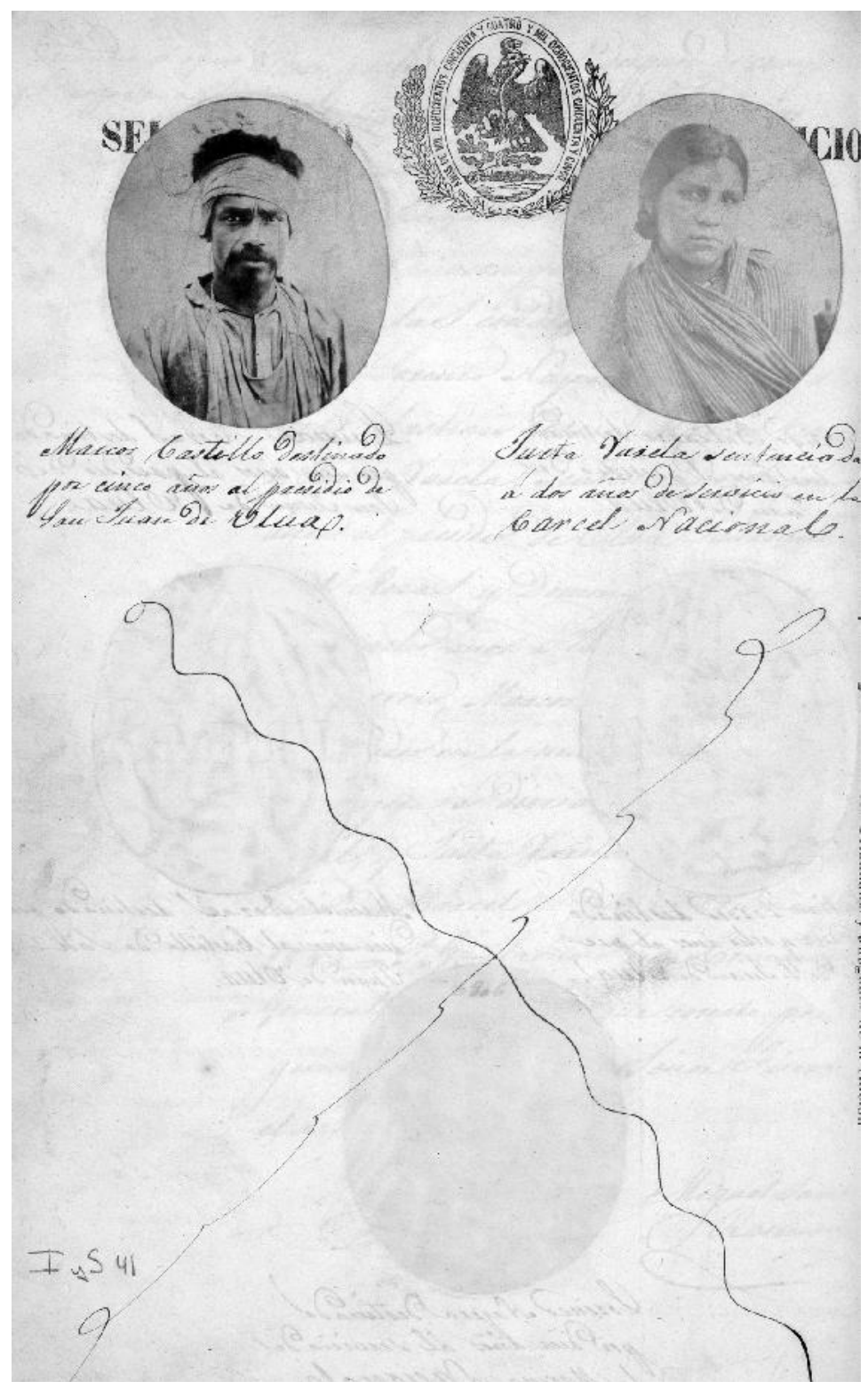


Por último, el 18 de junio de 1855 el comandante general Pedro González dio las sentencias definitivas de los reos: Manuel Rosas, Domingo Balcazar y Sebastián Zereso fueron condenados a pasar 18 años en el presidio de San Juan de Ulúa, Marcos Castillo cinco años en el mismo sitio, Lorenzo Nájera a 10 años en Marina Nacional y Justa Varela dos años en servicio a cárcel. Los retratos fotográficos de los presos fueron agregados a las diligencias del proceso criminal, estas fotografías son atribuidas al fotógrafo de cárcel José Muñoz.

\section{Proceso criminal contra Candelario Loa, José Pablo Policarpo, José Tranquilino, José Ángel, José Gabino Ponce, Cayetano Perea y Alvino Montaño, Prófugo por asalto y robo en cuadrilla en despoblado ${ }^{35}$}

La noche del 28 de agosto de 1854 una partida de ladrones, integrada por Candelario Loa, José Pablo Policarpo, José Tranquilino, José Gabino Ponce, Cayetano Perea y Alvino Montaño asaltaron el rancho propiedad de Martín Aguilar, situado en el monte y paraje llamado Cañada de los Ailes. La denuncia se realiza en el Juzgado de Calhuac y posteriormente el caso se remite al Juzgado de Paz de Santa Fe.

La noche del robo en el rancho, el dueño, Martín Aguilar, se encontraba en el Pueblo de Capulhuac arreglando unos asuntos, por lo que María Epitacia Acosta, su esposa; su hija Ignacia Aguilar, su yerno Rafael Rodea y su hijo de 13 años Vicente Aguilar se encontraban solos.

Rafael Rodea, al escuchar ladrar a los perros, abrió la puerta y fue sorprendido por los ladrones, quienes se introdujeron a la casa, excepto Candelario Loa quien se quedó afuera del rancho, los demás buscaron

35 AGn, "Proceso criminal contra: Candelario Loa, José Pablo Policarpo, José Tranquilino, José Ángel, José Gabino Ponce, Cayetano Perea y Alvino Montaño, por asalto y robo en cuadrilla en despoblado", Fondo Archivo de Guerra, vol. 47. 
y al no encontrar dinero tomaron todos los objetos que hallaron, además de comerse los huevos, la mantequilla y quesos que estaban ahí y se retiraron.

Los ladrones Candelario Loa y José Pablo Policarpo son aprendidos por el alcalde auxiliar de Cuajimalpa, y José Tranquilino, José Ángel, Cayetano Perea y José Gabino Ponce por el alcalde auxiliar de paz de Santa Fe, Ramírez. Junto con los ladrones se decomisan los objetos robados, los cuales se asientan en tres listas de registro, siendo remitidos al comandante general del Distrito de México, Francisco Y. Muñoz, coronel de Caballería Permanente y fiscal de Causas, encerrados en la Cárcel Nacional de Belem o ex-Acordada.

Se inician las averiguaciones por medio de declaraciones y careos de todas las partes, en los que todos los ladrones, excepto José Ángel, se declaran culpables, se hace el reconocimiento y entrega de las prendas robadas, las cuales equivalen a 192 pesos, dos reales y nueve granos, y el nombramiento de la defensa de los acusados por medio de una lista de los oficiales de guarnición disponibles.

Finalmente, se realizan las ratificaciones, las diligencias de entrega y se cita al Consejo de Guerra en la ex-Acordada, el 20 de junio de 1855, para dictar la sentencia, que es la siguiente: "se debería imponer la pena de último suplicio señalada en la Ley 18, título 14, partida 7 a. Pero tomando en consideración las circunstancias atenuantes (el poco monto de lo robado, no haber asesinatos ni maltratos, la recuperación de las prendas y "la imbecilidad e ignorancia de los ladrones", se sustituye por la de servicio en galeras en la Marina Nacional, José Pablo Policarpo y Gabino Ponce, 10 años de servicio, y Cayetano Perea, Candelario Loa y José Tranquilino, 10 años de servicio, según la Ley 2da., título 40, libro 12 de la Novísima recopilación y la 8va., título 31, partida 7a., a José Ángel lo liberan por ser inocente. 


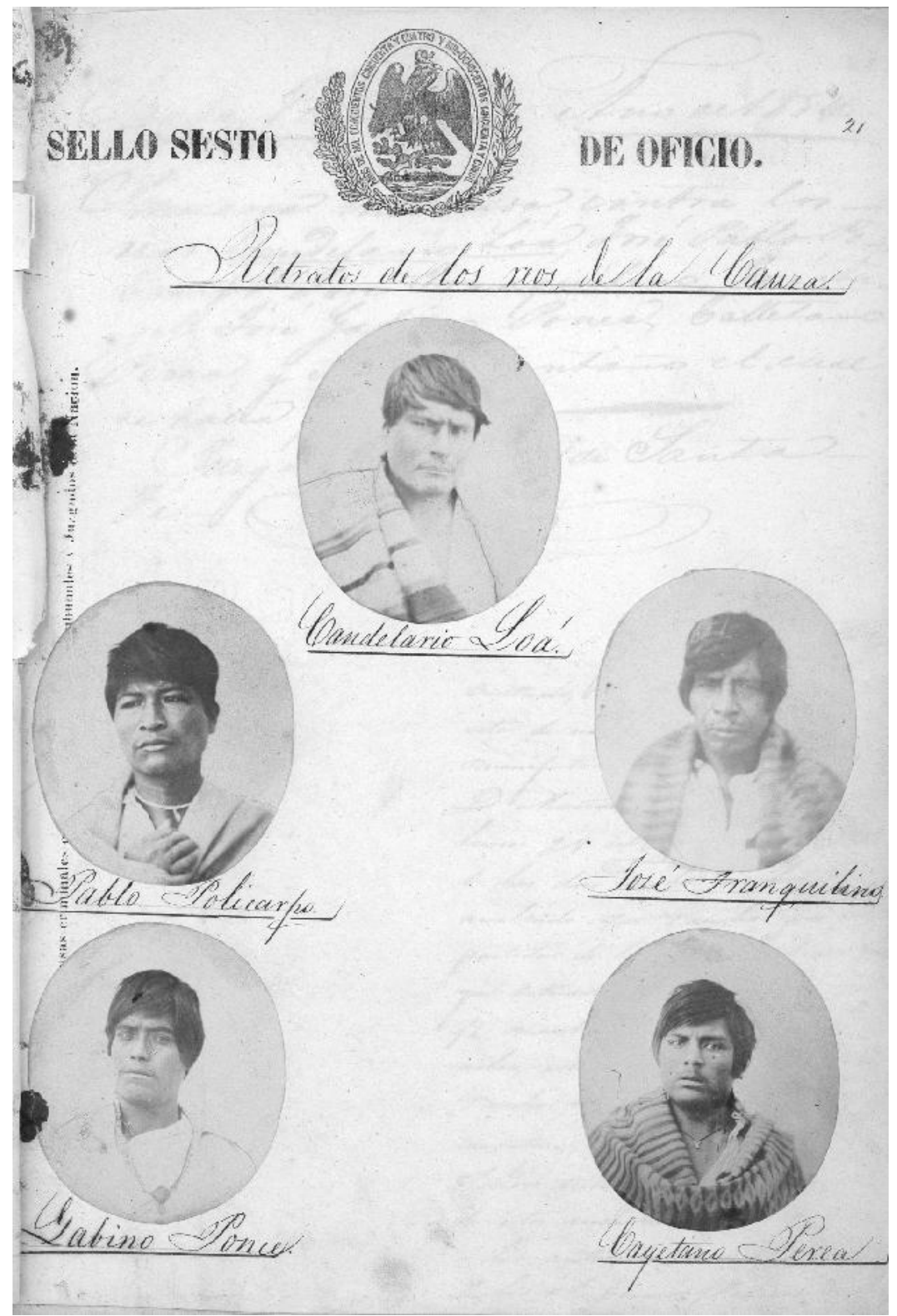

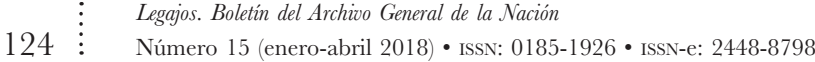




\section{Conclusiones}

Las impresiones fotográficas que se incluyen en los volúmenes 47 y 777 del Fondo Archivo de Guerra son hasta el momento los ejemplares más tempranos (1855) localizados en el AGN.

Son copias al papel salado, la cual fue la primera técnica de impresión fotográfica en realizarse por medio de un negativo por contacto y la cual permitió las copias en serie.

Se presume que ambas sesiones fotográficas fueron realizadas por el coronel José Muñoz, quien fue el fotógrafo oficial de la Cárcel Nacional de Belem en la década de 1850.

Nuestro país fue pionero en la normalización de la toma fotográfica como instrumento de identidad e identificación de criminales, que fue generalizado en muchos otros países hasta por lo menos un lustro después.

La Guerra de Independencia y las innumerables luchas por la soberanía del territorio y el poder político de nuestro país, dieron como resultado la inestabilidad política, la desorganización social, la desarticulación administrativa, la pobreza y el infranqueable contraste social caracterizado por enormes diferencias raciales y de clase, característicos de la mitad del siglo xIx. Por lo cual, las autoridades buscaron la modernización del sistema penitenciario aplicando métodos de control criminal acordes con los avances científicos, y la fotografía fue uno de ellos.

Ambos expedientes son muy cercanos en fechas de conclusión del proceso judicial y toma de retratos, por lo que son similares en las diligencias practicadas para la conclusión de la causa instruida, las complicaciones en la tardanza de los procedimientos, como el cambio constante de los defensores y las sentencias dictadas. 


\section{Fuentes}

\section{Archivos}

$\begin{array}{ll}\text { AGN } & \text { Archivo General de la Nación } \\ \text { AHDF } & \text { Archivo Histórico del Distrito Federal }\end{array}$

\section{Bibliografía}

Aguilar Ochoa, Arturo, Las glorias nacionales. Constantino Escalante, Hesiquio Iriarte, México, El Colegio de Puebla, 2012.

Buffington, Robert M., Criminales y ciudadanos en el México moderno, México, Siglo xxi Editores, 2001.

Debroise, Oliver, Fuga Mexicana. Un recorrido por la fotografia en México, Barcelona, Gustavo Gilli, 2005.

Lerner, Jesse, El impacto de la modernidad. Fotografia criminalística en la Ciudad de México, México, conaculta/inah, 2007.

Lozano Armendares, Teresa, La criminalidad en la Ciudad de México 1800-1821, México, Universidad Nacional Autónoma de México (UNAM), 1987.

MacLachlan, Colín M., La justicia criminal del siglo xvIII en México. Un estudio sobre el Tribunal de la Acordada, México, SepSetentas, 1976.

Valdez Marín, Juan Carlos, Conservación de fotografía histórica y contemporánea. Fundamentos y procedimientos, México, conaculta/inah, 2008.

Valverde Valdés, María Fernanda, Los procesos fotográficos históricos, México, Archivo General de la Nación, 2003. 
Vázquez, Josefina Zoraida, Historia general de México, México, El Colegio de México, 2000.

\section{Electrónicas}

Wordpress, 2013, Cesare Lombroso. Padre de la Criminología Cientifica, http:/sanchezlm.wordpress.com/2013/02/27/cesare-lombrosoel-padre-de-la-criminología-científica/. 